\title{
Writing the Histories of South Africa's Cities after Apartheid
}

Twentieth Century South Africa: A Developmental History. By Bill Freund (Cambridge: Cambridge U.P., 2018; pp. 288. £71.99);

Township Violence and the End of Apartheid: War on the Reef. By Gary Kynoch (Woodbridge: James Currey, 2018; pp. 240. £60);

Contradictions of Democracy: Vigilantism and Rights in Post-Apartheid South Africa. By Nicholas Rush Smith (Oxford: Oxford U.P., 2019; pp. 264. £64);

Trier, Exclure et Policier: Vies Urbaines en Afrique du Sud et au Nigeria. By Laurent Fourchard (Paris: P. de Sciences Po, 2018; pp. 365. €27);

Voices of Resilience: A Living History of the Kenneth Gardens Municipal Housing Estate in Durban. By Monique Marks, Kira Erwin and Tamlynn Fleetwood, with a photo essay by Cedric Nunn (Pietermaritzburg: U. of KwaZulu Natal P., 2018; pp. 319. ZAR 420);

Hostels in South Africa: Spaces of Perplexity. By Nomkosi Xulu-Gama (Pietermaritzburg: U. of KwaZulu Natal P., 2018; pp. 251. ZAR 719).

A quarter of a century after South Africa's democratic elections of 1994, this essay reviews how the work of a generation of radical historians, whose interests in urban history were forged in the crucible of apartheid, have shaped a new generation of urban history writing. At the peak of their influence in the I980s and early I990s, many of the older generation of historians were associated with a particularly vigorous branch of social history which researched the making of the South African working class. (Indeed, there have been many retrospectives on 'E.P. Thompson in African History'.) ${ }^{1}$ While many themes of social history have fallen into abeyance, in South Africa as elsewhere, I will discuss the ways in which these interests and commitments have inspired a new round of books that have been recently published on South Africa.

Looking back, it is startling to note how sharply the context in which South African historians wrote about cities and urban politics diverged from the experiences of scholars writing in the Global North in the I980s. With 'the forward march of labour' declared to be 'halted', even by Marxist intellectuals such as Eric Hobsbawm, the tide of historians

1 For instance, 'Journal of African History Roundtable: E.P. Thompson in African History', Journal of African History, li (2017), pp. I-59; F. Cooper, 'Work, Class and Empire: An African Historian's Retrospective on E.P. Thompson', Social History, xx (1995), pp. 235-4I; J. Hyslop, 'E.P. Thompson in South Africa: The Practice and Politics of Social History in an Era of Revolt and Transition, 1976-2012, International Review of Social History, lxi (2016), pp. 95-II6. 
working on themes of working-class and social history was ebbing in Britain and America at this time. ${ }^{2}$ By contrast, South Africa seemed on the cusp of revolution. It had the fastest growing, and one of the most militant, trade union movements in the Global South, whose numbers swelled from I7,000 to I.2 million in the I980s. Its cities burgeoned too, growing from 15.7 million to 24.4 million from I980 to I99I, as apartheid infrastructures of urban spatial segregation collapsed, generating new forms of what was then described as 'resistance'. ${ }^{3}$ Indeed, the midI980 saw the start of another round of township revolts that would ultimately bring to power Nelson Mandela's African National Congress at the head of a Tripartite Alliance that included an influential block of trade unionists and Communist Party intellectuals. These trends made late apartheid South Africa a centre of comparative radical scholarship. ${ }^{4}$ Take the example of Stan Greenberg, who would later become one of Bill Clintons' Third Way pollsters. Earlier, while an urban studies researcher and then co-director of Yale's Southern African Research Program (funded by the Ford Foundation), he wrote comparative studies, including Race and State in Capitalist Development (I980). ${ }^{5}$

Perhaps the most influential nexus of research in the late apartheid era took place under the aegis of the University of Witwatersrand History Workshop, established in 1977, in the context of the Durban Strikes (1973) and Soweto Revolt (1976). Recent retrospectives written by some members of the Wits History Workshop have emphasised the intellectual heterodoxy of their intellectual orientations, the diversity of their disciplinary backgrounds, and the range of their research interests. ${ }^{6}$ Nonetheless, a couple of features stand out. Institutionally, the core of the group was a circle of historians, many of whom had studied under

2 E. Hobsbawm, 'The Forward March of Labour Halted?', Marxism Today, September 1978, pp. 279-86.

3 For instance, P. Frankel, M. Pines and M. Swilling, eds., State, Resistance and Change in South Africa (London, 1988); S. Marks and S. Trapido, eds., Social History of Resistance in South Africa (Oxford, 1992); J. Wells, We Now Demand: The History of Women's Resistance to Pass Laws in South Africa (Johannesburg, 1993). The word 'resistance' still has great power: cf. W. Beinart and M. Dawson, eds., Popular Politics and Resistance Movements in South Africa (Johannesburg, 2010).

4 For instance: D. Denoon, Settler Capitalism: The Dynamics of Dependent Development in the Southern Hemisphere (Oxford, 1983); S. Greenberg, Race and State in Capitalist Development: South Africa in Comparative Perspective (London, 1980); G. Seidman, Manufacturing Militance: Workers' Movements in Brazil and South Africa, I970-1985 (London, 1994).

5 On the engagement of radical urban scholars with South Africa: The University of Virginia, Miller Centre Oral History Programme, interview with Stanley Greenberg, 27 January 2005, accessed at: https://millercenter.org/the-presidency/presidential-oral-histories/stanley-greenbergoral-history-2005-pollster. Also: C. Rassool 'Rethinking Documentary History and South African Political Biography', South African Review of Sociology, xli (2010), pp. 30-4.

6 For instance, P. Delius, 'E.P. Thompson, "Social History", and South African Historiography, 1970-90', Journal of African History, xi (2017), pp. 3-17-which, despite the title, is a critique of the Thompsonian tradition. See also: K. Breckenridge, 'Hopeless Entanglement: A Short History of the Humanities in South Africa', American Historical Review, cxx (2015), pp. I,253-66; I. Hofmeyr, 'South African Remains: E.P. Thompson, Biko and the Limits of the Making of the English Working Class', Historical Reflections, xli (2015), pp. 99-IIO; D. Posel 'Social History and the Wits History Workshop', African Studies, lxix (2010), pp. 29-40. 
Shula Marks at the Institute for Commonwealth Studies in London or with Stanley Trapido in Oxford. Intellectually, many were influenced by the strands of radical historiography that emphasised 'the making of the South African working-class' . In practical terms, this meant that the Wits History Workshop group shared many of the same strengths and blind-spots as their namesakes based at Ruskin College in Oxford. Yet there were special South African characteristics too. Stan Trapido, for instance, ran a weekly seminar in Oxford with the title '[from] peasant to worker', and many of his postdoctoral students studied the processes of labour migrancy that connected rural South Africa to the mines and cities. ${ }^{8}$ Another feature of South African social history research was a fascination with the popular culture and political resistance of the black townships and locations in South Africa's burgeoning cities. ${ }^{9}$

In one sense, the early/mid-I990s, which were the first years of South Africa's democratic government, marked the apogee of the History Workshop and their allies. Many academics were drawn into the urban redevelopment forums and committees that discussed the rebuilding of post-apartheid cities. Members of Wits History Workshop were even commissioned by government to write a series of semi-official histories of a number of townships along the Witwatersrand as part of the process of urban reconstruction. ${ }^{10}$ At the same time, academics from a more diverse array of disciplines, employing self-consciously postmodern perspectives, now moved to make a sustained critique of

7 Retrospectives include: P. Bonner, 'New Nation, New History': The History Workshop Journal in South Africa, I977-1994', Journal of American History, lxxxi (1994), pp. 977-85; B. Bozzoli and P. Delius, 'Radical History and South African Society', Radical History Review, xlvi, (1990), pp. 13-45; A. Lissoni, N. Nieftagodien and S. Ally, 'Introduction: "Life after Thirty"-A Critical Celebration', African Studies, lxix (20I0), pp. I-I2. Other anchor publications within the wider field include: F. Cooper, On the African Waterfront: Urban Disorder and the Transformation of Work in Colonial Mombasa (New Haven, CT, I987); F. Cooper, ed., Struggle for the City: Migrant Labour, Capital and the State in Urban Africa, (London, 1983); R. Sandbrook and R. Cohen, eds., The Development of an African Working Class: Studies in Class Formation and Action (London, 1975).

8 P. Delius, 'E.P. Thompson', p. 6. On South Africa's transition to capitalism: S. Marks and A. Atmore, eds., Economy and Society in Pre-Industrial South Africa (London, 1980); S. Marks and R. Rathbone, eds., Industrialisation and Social Change in South Africa: African Class Formation, Culture, and Consciousness, I870-1930, (Harlow, I982); S. Marks and S. Trapido, eds., The Politics of Race, Class and Nationalism in Twentieth Century South Africa (London, 1987). Succinct summaries of labour migration debates include: K. Breckenridge, 'Promiscuous Method: The Historiographical Effects of the Search for the Rural Origins of the Urban Working Class in South Africa', International Labor and Working-Class History, lxv (2004), pp. 26-49; J. Ferguson, Expectations of Modernity: Myths and Meanings of Urban Life in the Zambian Copperbelt (Berkeley, CA, 1999), pp. 86-93.

9 For instance, P. Bonner, I. Hofmeyr, D. James and T. Lodge, eds., Holding Their Ground: Class, Locality and Culture in Nineteenth and Twentieth Century South Africa (Johannesburg, 1989); B. Bozzoli, ed., Class Community and Conflict (Johannesburg, 1987); D. Coplan, In the Township Tonight: South Africa's Black Music and Theatre (London, 1985).

10 P. Bonner and N. Nieftagodien, Kathorus: A History (Johannesburg, 20oI); P. Bonner and L. Segal, Soweto: A History (Cape Town, 1998); P. Bonner and N. Nieftagodien, Alexandra: A History (Johannesburg, 2008); P. Bonner and N. Nieftagodien Ekurhuleni: The Making of an Urban Region (Johannesburg, 20I4). 
this tradition of social history. Rather than writing bounded histories of individual black townships, the new scholars took a broader view of Africa's cities as laboratories of a cosmopolitan Afro-modernity. AbdouMaliq Simone, working at the African Centre for Migration and Society at the University of Witwatersrand, for instance, influentially described decaying downtown Johannesburg as a place in which urban Africans, living in precarious conditions, created new forms of cohesion and sociability out of cosmopolitan social networks. ${ }^{11}$ The most powerful intervention in this vein was the special issue of Public Culture, edited by Achille Mbembe and Sarah Nuttall, Johannesburg: The Elusive Metropolis (2004). ${ }^{12}$ This issue-later reworked into book form-was strongly influenced by literary and film scholars whose work described representations of urban living. Taken together, these scholars made the argument that the cities of Africa and the Global South-Johannesburg, Lagos and Mumbai-should feature just as prominently in global debates as the centres of finance capital- New York, London and Shanghai. ${ }^{13}$

At the same time, a postmodern vision of a cosmopolitan Afromodernity sits uneasily with the older radical traditions of scholarship that seek to emphasise the enduring historical patterns of inequality that are seared into the fabric of South Africa's cities. (After all, South Africa remains one of the most unequal societies in the world.) This is the context in which 'many writers [have] continued within traditions that direct attention to the economic and spatial materialities of the city', including the books under review here..$^{14}$

The first book reviewed is Twentieth Century South Africa: A Developmental History, written by Bill Freund, an American economic historian domiciled in Durban since the mid-I980s. One reason to start here is that the author's long association with this South African city on the Indian Ocean seaboard (previously he had worked at Ahmadu Bello University, Zaria, Nigeria) provides a window onto the evolution of radical scholarship across the decades.

11 A. Simone, 'People as Infrastructure: Intersecting Fragments in Johannesburg', Public Culture, xvi (2004), pp. 407-29.

12 A. Mbembe and S. Nuttall, 'Writing the World from an African Metropolis', Public Culture, xvi (2004), pp. 347-72.

13 L. Bremner, Writing the City into Being: Essays on Johannesburg, 1998-2008 (Johannesburg, 20Io); J. Robinson, Ordinary Cities: Between Modernity and Development (Oxford, 2006); A. Simone, 'On the Worlding of African Cities', African Studies Review, xliv (200I), pp. I5-4I. For a memoir that artfully weaves between the divergent literatures: J. Dlamini, Native Nostalgia (Johannesburg, 2009).

14 P. Harrison, G. Gotz, A. Todes and C. Wray, 'Materialities, Subjectivities and Spatial Space, Changing City: Johannesburg After Apartheid (Johannesburg, 20I4), p. I7. 
In the mid-I980s, Durban was the ideal berth for an economic historian particularly interested in productive processes and the genesis of class formation. Having been the centre of the 1973 Strike Wave, the city was the headquarters of the Federation of South African Trade Unions (FOSATU) from 1979 to 1985 . It was also an important intellectual centre, publishing the South African Labour Bulletin and the first book to reflect on the upsurge of industrial protest, The Durban Strikes: Human Beings with Souls (1974). ${ }^{15}$ One protagonist later described this book as South Africa's 'first sociological study of the new type of [black] industrial worker: the semi-skilled, machine operator' who formed the backbone of the nascent trade unions. ${ }^{16}$ At the same time, many Durban intellectuals in the r980s and early I990s - much like their colleagues in the Wits History Workshop based in Johannesburg-were expanding their field of view to incorporate a broader vision of urban popular culture. In the I980s and I990s, separate clusters of historians based in Durban, Cape Town and the urban Transvaal/Johannesburg each produced social histories of their home cities. ${ }^{17}$ Important, too, were wider projects of public engagement: the photo essays on squatter settlements and the textiles factories produced by the Institute for Black Research; the photo agency Afrapix; and the biographies of black trade unionists written by the Culture and Working Life Project. ${ }^{18}$ These shifts were also reflected in Bill Freund's writing. His first books included Capital and Labour in the Nigerian Tin Mines (198I) and The African Worker (1988). Later, he wrote Insiders and Outsiders: The Indian Working Class of Durban I9I0-I99o (I995), a history of class and community, which followed indentured labourers from the peri-urban sugar plantations to the segregated working-class townships of high apartheid.

Freund's latest title is an important landmark, showing the transformation of radical scholarship in recent years. His ambition is to write 'a new kind of economic history', which thinks through the trajectory of South Africa's industrial development across the twentieth century. ${ }^{19}$ Most immediately, the book engages with a very specific strand of debates about the historical origins of the 'developmental

15 F. Fisher and G. Mare, The Durban Strikes: Human Beings with Souls (Durban, 1974).

16 E. Webster, 'Review: Choosing to be Free: The Life Story of Rick Turner by Billy Keniston' Transformation, lxxxv (2014), p. I49. On this 'Durban Moment': J. Copelyn, Maverick Insider: A Struggle for Union Independence in a Time of National Liberation (Johannesburg, 2016).

17 P. Maylam and I. Edwards, eds., The People's City: African Life in Twentieth Century Durban (Pietermaritzburg, 1996). V. Bickford-Smith, E. van Heyningen and N. Worden, Cape Town in the Twentieth Century: An Illustrated Social History (Cape Town, 1999); C. van Onselen, Studies in the Social and Economic History of the Witwatersrand, I886-19I4. Vol. I: New Babylon; Vol 2: New Ninevah (London, 1982).

18 J. Fairbairn, Flashes in Her Soul: The Life of Jabu Ndlovu (Pietermaritzburg, 199I). H. Hughes and O. Badsha, Imijondolo: A Photographic Essay on Forced Removals in the Inanda District of South Africa (Durban, 1985); F. Meer, The Divided Lives of South Africa's Women Workers (Durban, I984); A. Qabula, A Working Life, Cruel beyond Belief (Johannesburg, 1989).

19 B. Freund, Twentieth Century South Africa: A Developmental History (Cambridge, 2019), p. I2. 
state' in East Asia, Latin America and Africa. In the I990s, economists and political scientists such as Ann Amsden, Ha-Joon Chang and Robert Wade popularised the notion that the East Asian economic miracle had taken place within a specific institutional/historical context. ${ }^{20}$ More recently, these ideas have become influential amongst South African policy-makers, who compare the torpid growth rates of the post-apartheid era (geographically) to their sub-Saharan neighbours and (historically) to their predecessors in the apartheid government. ${ }^{21}$ Freund argues that apartheid South Africa was a developmental state of sorts, pursuing what has been described as a project of 'racial Fordism', that is, a growth strategy in which a racially segregated white population enjoyed the goods of suburban society. Yet the institutions and urban planning strategies that had organised and built South Africa's modern, segregated industrial cities unravelled in the final years of apartheid, because of both economic stagnation and the urban revolts. ${ }^{22}$ In a final chapter, Freund speculates on what sort of state interventions would be required to rebuild South Africa's cities along productive, more equitable, post-apartheid lines.

But is Freund's book a new economic history? In one sense, the developmental state literature, with its focus on the structural and institutional foundations of economic life, is an aeon away from the social history approaches of the I980s and I990s concerned with questions of class consciousness and culture. (The table of contents is telling: Chapter Nine is on 'energy and natural environment'; Chapter Seven on the 'Key Institutions' of development-the Industrial Development Corporation, the Council for Scientific and Industrial Research and the Human Sciences Research Council.) At the same time, Freund's 'developmental history' engages in a fruitful dialogue with some of the strands of older social histories.

For one, a number of the Wits History Workshop historians and their interlocutors had been deeply interested in questions of state formation and the institutions of apartheid governance. ${ }^{23}$ More broadly, all the protagonists of the 1970s/1980s social history debates situated their Economies (Oxford, 200I); H.-J. Chang, The East Asian Development Experience: The Miracle, the Crisis and the Future (New York, 2006); R. Wade, Governing the Market: Economic Theory and the Role of Government in East Asian Industrialization (Princeton, NJ, 1990).

21 W. Gumede, 'Delivering a Democratic Developmental State in South Africa', Development Bank of Southern Africa, Policy Brief No. I, Feb. 20II; B. Turok with H.-J. Chang and J. Ferraz, Development in a Divided Country: Understanding the ANC Today (Johannesburg, 20II). See also: T Kelsall, Business, Politics and the State in Africa: Challenging the Orthodoxies of Growth and Transformation (Cambridge, 2013).

22 S. Gelb, South Africa's Economic Crisis (London, 199I); G. Williams, 'Why Structural Adjustment is Necessary and Why it Doesn't Work', Review of African Political Economy, lx (1994), pp. 2I4-25. (Oxford, 1991). 
research in a much wider set of arguments about the development of capitalism in South Africa. These earlier controversies-on the role of 'cheap, unskilled migrant labour' or 'the Minerals-Energy Complex', for example-provide important antecedents to contemporary debates about the economic/developmental crisis faced in post-apartheid South Africa. ${ }^{24}$ Freund's new book (as does the work of others) takes forward these questions in a novel fashion. ${ }^{25}$

Another striking aspect of Freund's book is the way in which cities emerge as developmental actors in their own right. There is a chapter on the company towns of the Vaal Triangle (which lies to the south of Johannesburg). This was a purpose-built urban landscape, constructed along modernist lines, for the heavy industries of the post-war era that were at the heart of apartheid patterns of economic growth. There are also sharp pen-portraits of the industrialists who shaped the urban landscape of South Africa-not least Philip Frame, whose textile mills transformed the port city of Durban into one of the global centres of the clothing industry at the height of apartheid. Freund's description of the municipal government and business coalitions that drove South Africa's industrial growth during the apartheid era are important for policy circles, as new generations of urban officials ponder how to revive the South African economy. ${ }^{26}$ Freund's work also intersects with a new wave of research that studies the infrastructures of city building-industrial and urban planning, transport, housing and real estate, and even the provision of schooling. ${ }^{27}$ While awkwardly written in places, this is an important book that opens up new fields of urban research.

24 Reading Freund's footnotes, one sees the depth of these debates. Important interventions include: B. Fine and Z. Rustomjee, The Political Economy of South Africa: From Mineral-Energies Complex to Industrialisation, (London, 1996); T. Moll, 'Did the Apartheid Economy Fail?' Journal of Southern African Studies, xvii (199I), pp. 27I-9I; J. Seekings and N. Nattrass, 'The Economy and Poverty in the Twentieth Century', in R. Ross, A. Mager and B. Nasson, eds., The Cambridge History of South Africa (Cambridge, 2014), pp. 518-72; S. Trapido, 'South Africa in a Comparative Study of Industrialization', Journal of Development Studies, vii (197I), pp. 309-20; H. Wolpe, 'Capitalism and Cheap Labour-Power in South Africa: From Segregation to Apartheid', Economy and Society, i (1972), pp. 425-56.

25 S. Dubow and A. Jeeves, eds., South Africa's I940s: Worlds of Possibilities (Cape Town, 2005); H. Marais, South Africa Pushed to the Limit: The Political Economy of Change (London, 200I); J. Seekings and N. Nattrass, Policy, Politics and Poverty in South Africa, 1994-2009 (Basingstoke, 20I5).

26 B. Freund, 'City Hall and the Direction of Development: The Changing Role of the Local State as a Factor in Economic Planning and Development in Durban,' in B. Freund and V. Padayachee, eds., (D)urban Vortex: South African City in Transition (Pietermaritzburg, 2002) pp. II-4I.

27 L. Bank, City of Broken Dreams: Myth-Making, Nationalism and the University in an African Motor City (Cape Town, 2019); M. Epprecht, Welcome to Greater Edendale: Histories of Environment, Health, and Gender in an African City (London, 2016); P. Harrison et al., eds., Changing Space, Changing City; M. Hunter, Race for Education: Gender, White Tone, and Schooling in South Africa (Cambridge, 2019); F. Locattelli and P. Nugent eds., African Cities: Competing Claims on Urban Spaces (Leiden, 2009); S. Sparks, 'Apartheid Modern: South Africa's Oil from Coal Project and the History of a Company Town', (Univ. of Michigan Ph.D. thesis, 20I2). 
The second set of books under review broadly considers questions of crime and policing. This new focus of research (which fits with trends seen in urban studies across the Global South) has particular resonance in South Africa's cities, given that persistently high rates of violent crime have been linked to the urban inequalities characteristic of settler colonialism and apartheid. Here, a new generation of historians and urban studies scholars have subtly changed their fieldwork: rather than studying delinquents, bandits and class resistance, they are now interested in vigilantes, urban governance and grassroots networks of power.

Gary Kynoch's research on the mining/industrial towns along the Witwatersrand, centred on Johannesburg, provides a useful starting point to see how these research themes have evolved. His first book, on 'Russian' gangs_-groups of Sesotho-speaking migrant labourers who organised protection rackets in the squatter settlements and on the edges of the mining compounds-engaged with one of the classic themes of social banditry. ${ }^{28}$ Since then, he has written more broadly about crime and policing in urban South Africa. ${ }^{29}$ The book under review, Township Violence and the End of Apartheid: War on the Reef, now looks at the links between township criminality and South Africa's political violence. This is an important theme: during the constitutional talks that ran from I990 until South Africa's first democratic elections in April 1994, I4,000 lives were lost in a quasi-civil war that almost derailed the democratic transition. Kynoch's book is particularly interesting in that it is the first full-length monograph to focus on the industrial townships along the Eastern Witwatersrand as well as on the southern townships of the Vaal Triangle, which saw some of the fiercest fighting during that time. Here, apartheid security forces, working hand-in-glove with vigilante groups from Inkatha yeSizwe (the Zulu Movement for National Cultural Liberation), fought against Self Defence Units loosely aligned to Nelson Mandela's African National Congress (ANC).

Following the arguments made popular by the political scientist Sthathis Kalyvas, Kynoch notes that 'although civil wars are typically defined by a "master cleavage"... [it is] tangential "local cleavages" [that] frequently drive the violence on the ground'. ${ }^{30}$ Like many recent

28 G. Kynoch, We are Fighting the World: A History of the Marashea Gangs in South Africa, 1947-1999 (Athens, NH, 2005). A classic first study: C. van Onselen, 'Crime and Total Institutions in the Making of Modern South Africa: The Life of "Nongoloza" Mathebula I867-1948', History Workshop Journal, ixx (1985), pp. 62-8I.

29 G. Kynoch, 'Urban Violence in Colonial Africa: A Case for South African Exceptionalism', Journal of Southern African Studies, xxxiv (2008), pp. 629-45; G. Kynoch, 'Apartheid's Afterlives: Violence, Policing and the South African State' Journal of Southern African Studies, xlii (2016), pp. $65-78$.

30 G. Kynoch, Township Violence and the End of Apartheid: War on the Reef(Harlow, 20I7), 
books on political violence and vigilantism in South Africa, Kynoch is particularly interested in 'the [localised] intersections between political and criminal violence' in urban areas. Rather than focusing on the 'master cleavage' between the ANC and Inkatha/apartheid security forces, Kynoch focuses on how local networks of crime, racketeering and petty accumulation were sucked into the political violence. In one sense, these are not new topics. Radical historians from the Wits History Workshop, such as Vusi Ndima, Noor Nieftagodien and the late and much-loved Phil Bonner have written insightfully on how mafia-like minibus-taxi associations (which carried around 60 per cent of urban commuters) were drawn into the political violence in key townships along the Witwatersrand. ${ }^{31}$ Others have written extensively on the way in which 'shack-lords' (men who controlled informal settlements, demanding rents and fees from inhabitants) from the fringes of South Africa's cities were transformed into 'warlords' during the final years of apartheid. ${ }^{32}$ At the same time, Kynoch's exhaustive research provides fascinating new material. Chapter Five and Six, in particular, provide impressive narratives of how the conflicts played out differently in two different townships. This is complex, often painful material that is handled with great sensitivity.

Another notable quality of this book is the commitment to detailed oral history research - a feature of the old traditions of social history in South Africa, also seen in much of the new generation of research. To complete the book, Gary Kynoch and his research assistant, Zodwa Radebe, conducted more than one hundred interviews with a wide variety of people, from both sides of the political divide, in the migrant hostels and the township sections that saw some of the most brutal violence. This is a remarkable achievement; yet the silences should be noted too. Whilst Kynoch and Radebe successfully obtained interviews with politicians linked to the ANC, they were less successful in accessing the leaders from the Inkatha Freedom Party. Such lacunae are inevitable. Jonny Steinberg's recent book on policing brilliantly described South Africa's cities-from the rich, gated communities in the northern suburbs, to the migrant hostels run by minibus-taxi mafias — as being like a series of cells which even the agents of the state,

31 P. Bonner and V. Ndima, 'The Roots of Violence and Martial Zuluness on the East Rand', in B. Carton and J. Laband, eds., Zulu Identities: Being Zulu, Past and Present (London, 2009), pp. 363-8I; P. Bonner and N. Nieftagodien, 'The TRC and the Pursuit of Social Truth: The case of Katorus', in D. Posel and G. Simpson, eds., Commissioning the Past: Understanding South Africa's Truth and Reconciliation Commission (Johannesburg, 2002), pp. 173-98; M. Khosa, 'Routes, Ranks and Rebels: Feuding in the Taxi Revolution', Journal of Southern African Studies, xviii (I992), pp. 232-5I.

32 D. Hindson, M. Byerley and M. Morris, 'From Violence to Reconstruction: The Making, Disintegration and Remaking of an Apartheid City', Antipode, xxvi (1994), pp. 323-50; H. Sapire, 'Politics and Protest in Shack Settlements of the Pretoria-Witwatersrand-Vereeniging Region, South Africa, 1980-1990', Journal of Southern African Studies, xviii (1992) pp. 670-97. 


\section{Page io of I7 WRITING THE HISTORIES OF SOUTH AFRICA'S}

such as the police, find it difficult to penetrate. ${ }^{33}$ One of the great strengths of Kynoch and Radebe's fieldwork (as with so much South African research) is their determination to insinuate their way into, and explain, these cellular structures of city life.

Kynoch's book ends with the depressing conclusion that South Africa's persistently high rates of urban crime (which tend to peak in particular city townships) are a legacy of late apartheid. By contrast, Nicholas Rush Smith's monograph, Contradictions of Democracy: Vigilantism and Rights in Post-Apartheid South Africa, begins with the startling observation that most urban South Africans enjoy increasing security: murder rates have broadly halved since 1994. So why does South Africa still experience 'extraordinarily high rates of vigilantism despite a celebrated transition to democracy, a lauded constitution, and massive transformations of the state's legal apparatus following apartheid'?34 Smith argues that, ironically, it is the dense networks of neighbourly solidarity and civic association in the townships that lie behind the rise in vigilante activity. Robert Putnam described civic associations as a font of democratic virtue; Smith's argument is far more sinuous. He argues that post-apartheid state institutions have failed to penetrate these dense networks of neighbourliness and solidarity; hence the increasingly fraught relationship between vigilantes and the law.

Smith's book situates itself in debates about state formation from below. At the same time, it can be read as a book of urban anthropology, given that the most sustained fieldwork featured in the book was done in Durban's KwaMashu Township and the southern townships of the Gauteng city region. Indeed, the book provides a striking example of how anthropological approaches are making inroads into the field of urban studies. An anthropologist trained at the University of Chicago-which has become increasingly influential in South Africanist debates in recent years, eclipsing the older History Workshop approaches ${ }^{35}$ - Smith's book is very sensitive to the latest debates in the field. One of the important contributions of this book is to weave the more locally focused South African literature into a wider theoretical and comparative framework. Interesting too is the conversational style of writing. We see on the page that Smith lives in the cities that he writes about: driving into townships, walking down back-roads, buying food in spaza shops, talking to friends and field-workers. The 'lofty and magisterial' style of social history, typical of Charles van Onselen (or E.P. Thompson, for that matter), has been replaced by a far more Africa (Oxford, 2019), p. I5.

35 Smith is numbered among the cohort of dissertation students supervised by the prolific South African anthropologists Jean and John Comaroff, whose latest book is The Truth about Crime: Sovereignty, Knowledge, Social Order (Chicago, IL, 2016). 
ambivalent relationship between author and subject, which gestures towards the fluidity and uncertainty of urban life. ${ }^{36}$

Laurent Fourchard's book, Trier, Exclure et Policier: Vies Urbaines en Afrique du Sud et au Nigeria [Sort, Exclude and Police: Urban Lives in South Africa and Nigeria], is the third title under review here. Fourchard has written a number of important articles in British and American journals, but has chosen to write this book in French and have it published by the Presses de Sciences Po. One might read this hopefully, as a sign of the increasing importance of Francophone research networks in South African urban studies, a field that in the I970s and I980s was dominated by Anglo-South African institutions. Indeed, Fourchard's professional career is illustrative of these trajectories. The Nigerian half of the book has its origins in his directorship of the French Institute of Research in Africa, Nigeria (IFRA; established inI990), a centre jointly funded by the French Foreign Affairs Ministry and the Centre for Scientific Research (CNRS). Collaborating closely with Nigerian colleagues-IFRA is integrated into the University of Lagos_-Fourchard co-edited a number of books on urban life in West Africa, which straddled the Francophone and Anglophone divides in the region. The South African tranche of research was then largely done in 2008-9, when Fourchard was a visiting scholar at the University of Cape Town and in close contact with the French Institute of Research in Africa, Johannesburg (established in 1995). ${ }^{37}$ More recently, he has worked at the Centre for International Research (CERI) in well-funded 'research laboratories' concerned with the study of cities and citizenship, which have brought cohorts of South African researchers to Paris. ${ }^{38}$

The fruit of these centrally organised and well-funded Francophone networks is seen in Fourchard's new book, a heavyweight comparative study, richly-larded with case-studies of Lagos, Ibadan, Kano, Cape Town and the PWV (Pretoria-Witwatersrand-Vereeniging) city region. Part I lays the comparative historical foundations. Fourchard argues that the mid-twentieth century colonial/settler state 'sorted'39 and 'excluded' urban populations — by race and ethnicity in South Africa, and between separating locals/indigenes from outsiders in Nigeria. This, argues Fourchard, created categories of governance that persist into the present day. The link that Fourchard suggests between Nigeria and South Africa is an interesting and

36 L. de Kock, 'Two Generations of South African Non-Fiction', The Johannesburg Review of Books (6 May 2015), accessed at: http://lareviewofbooks.org/review/ two-generations-of-south-african-nonfiction.

37 These research networks produced two edited books: S.B. Bekker and L. Fourchard, eds., Governing Cities in Africa (Cape Town, 2013); L. Fourchard, ed., Gouverner les Villes d'Afrique: Etat, Gouvernement Local et Acteurs Privés (Paris, 2007).

38 In total, the French Institute for Foreign Research (IFRE) boasts 27 research centres, including offices in Nigeria, South Africa and Kenya.

39 To sort/trier is a resonant word for Francophones, redolent of sorting household waste into recycling bins. Indeed, there are important monographs and articles about 'the recycled city': cf. G.A. Myers, Disposable Cities: Garbage, Governance and Sustainable Development in Urban Africa (Aldershot, 2005). 


\section{Page I2 of I7 WRITING THE HISTORIES OF SOUTH AFRICA'S}

provocative comparison. Often, South Africa's historical trajectory is seen as exceptional: a narrative in which the discovery of gold and diamonds in the late nineteenth century led to a brutal industrialisation, resulting in the rise of a powerful apartheid state at a time when much of the continent was decolonising. In consequence, South Africa typically receives a separate chapter in general histories of the continent and African urban life. Fourchard, by contrast, suggests that the cities of Nigeria and South Africa do bear comparison: for both colonial and settler regimes characterised cities as dangerous spaces, dominated by delinquents, slum settlements and thick networks of criminal/informal activity.

The denouement comes in Part III, which discusses contemporary urban politics. Chapter Five ('Big Men and Urban Rents') discusses how the politics of urban development-infrastructure investment, transport modernisation, a new drive to collect taxes-have allowed Nigerian politicians to renew the politics of clientage. This is an important intervention into West African debates about urban renewal; it is a shame the comparisons are not extended to South Africa, where urban scholars are beginning to investigate parallel forms of patronage politics in the post-apartheid era. ${ }^{40}$ Chapter Six ('Exclusion at the Ticket Gate') then contrasts the politics of patronage and 'inclusion' against the politics of 'exclusion' and xenophobia that is particularly seen in South Africa as well as certain West African cities. ${ }^{41}$ This is a bold, broad, richly illustrated argument (and, I might add, a cogently written book, which can be easily read and digested by non-native French speakers) which I hope will find an Anglophone audience.

\section{III}

If Laurent Fourchard's research shows the strength of Francophone publishing, the next pair of titles under review are distinctive in being

40 On South Africa: C. Bénit-Gbaffou, ed., Popular Politics in South African Cities: Unpacking Community Participation (Pretoria, 20I5); A. Beresford, 'Patronage, Power and Gatekeeper Politics in South Africa', African Affairs, cxiv (2015), pp. 226-48; H. Dawson, 'Patronage from Below: Political Unrest in an Informal Settlement in South Africa', African Affairs, cxiii (20I4), pp. 518-39. See also: A Joshi and J. Ayee, 'Associational Taxation: A Pathway into the Informal Sector?', in D. Brautigam, O.-H. Feldstad and M. Moore, eds., Taxation and State-Building in Developing Countries: Capacity and Consent (Cambridge, 2008), pp. I83-2II; D. Gramont, 'Governing Lagos: Unlocking the Politics of Reform', (Carnegie Endowment for Peace, Jan. 2015), accessed at http://carnegieendowment.org/files/governing_lagos.pdf; M. Rizzo, 'The Political Economy of an Urban Mega-Project: The Bus Rapid Transport Project in Tanzania', African Affairs, cxiv (2014), pp. 249-70.

41 On South Africa's xenophobic violence: S. Hassim, T. Kupe and E. Worby, eds., Go Home or Die Here: Violence, Xenophobia and the Reinvention of Difference in South Africa (Johannesburg, 2008); L. Landau, ed., Exorcising the Demons Within: Xenophobia, Violence and Statecraft in Contemporary South Africa (Tokyo, 20I2). On West African communal violence, see: A Higazi, 'Violence Urbaine et Politique à Jos (Nigeria), de la Période Colonial aux Elections de 2007', Politique Africaine, cvi (2007), pp. 69-9I; A.R. Mustapha and D. Erhard, eds., Creed and Grievance: Muslim-Christian Relations and Conflict Resolution in Northern Nigeria (Harlow, 2019). 
published by South Africa's thriving university presses which today offer a platform for a widening range of urban studies research. The books under review here are written by researchers associated with the new Urban Futures Centre established by the Durban University of Technology, the city's old technikon/polytechnic. Both titles are distinctive in that they offer intriguing insights into how researchers might think about the histories of 'social housing, urban planning and regulation, identity formation and change'. ${ }^{42}$

Voices of Resilience: A Living History of the Kenneth Gardens Municipal Housing Estate in Durban (2018), by Monique Marks, Kira Erwin and Tamlynn Fleetwood, offers a fascinating micro-study that is suggestive of much wider changes in South Africa's urban landscape. Kenneth Gardens was built for 'poor whites' in 1948, the year the National Party came to power on the platform of apartheid separate development. South African historians have written extensively about how apartheid planners' modernist vision reshaped South Africa's cities in the years that followed, and about the bulldozing of mixed-race slums, and the forced removals of these populations to separate, racially segregated townships which were built on the peripheries of the cities near to the newlybuilt factory estates. ${ }^{43}$ They have also discussed apartheid's creation of a white middle-class suburbia, predicated on one of the highest rates of car-ownership in the world. (In the I960s, when Toyota and Ford were building new plants in South Africa's cities, white South Africans enjoyed the fourth highest rates of car-ownership, eclipsed only by Australia, Canada and, of course, the USA. ${ }^{44}$ Yet there has been much less literature on the working-class housing projects designed for 'poor whites', which were also an integral part the apartheid government's urban vision. In this sense Kenneth Gardens-part of a cluster of housing estates, filling in the space between the industries of Umbilo and the middle-class neighbourhoods of Glenmore and Glenwoodwas an important part of apartheid's urban mosaic. ${ }^{45}$

42 Monique Marks, Kira Erwin and Tamlynn Fleetwood, Voices of Resilience: A Living History of the Kenneth Gardens Municipal Housing Estate in Durban (Pietermaritzburg, 2018), p. 5

43 L. Bank, Home Spaces, Street Styles: Contesting Power and Identity in a South African City (London, 20II); R. Lee, African Women and Apartheid: Migration and Settlement in Urban South Africa (London, 2009); J. Robinson, The Power of Apartheid: State, Power and Space in South African Cities (Oxford, 1996).

44 W. Beinart, Twentieth Century South Africa (Oxford, 1994), pp. 174-5. Also: D. Duncan, We are Motor Men: The Making of the South African Car Industry (Caithness, 1997); J. Hyslop, 'Why did Apartheid's Supporters Capitulate? "Whiteness", Class and Consumption in Urban South Africa, 1985-1995', Society in Transition, xxxi (2000), pp. 36-44; D. Posel, 'Races to Consume: Revisiting South Africa's History of Race, Consumption and the Struggle for Freedom', Ethnic and Racial Studies, xxxiii (2010), pp. 157-75.

45 I. du Plessis, 'Living in "Jan Blom": Making and Imagining Lives after Apartheid in a Council Housing Scheme in Johannesburg', Current Sociology, lii (2004), pp. 879-908; P. Harrison and T. Zack, 'The Wrong Side of the Mining Belt: Spatial Transformations and Identities in Johannesburg's Southern Suburbs', in P. Harrison et al., eds., Changing Space, Changing City, pp. 269-9I; A. Teppo, The Making of a Good White: A Historical Ethnography of the Rehabilitation of Poor Whites in a Suburb of Cape Town (Helsinki, 2004). 


\section{Page I4 of I7 WRITING THE HiSTORIES OF SOUTH AFRICA'S}

Not only is Voices of Resilience a welcome contribution to the literature on the making of apartheid, it is also a shrewd analysis of the collapse of apartheid urban modernism from the I980s onwards. As pass laws restricting black settlement in the cities fell away and much of this public housing stock was sold-off, many white working-class suburbs of South Africa's cities (to use the parlance of the time) 'greyed'.46 South African urbanists, much like their North American brethren, have tended to highlight the spectacular, and sometimes apocalyptic, hollowing-out of city centres-for instance, the 'hijacking' of the art I4.IO deco high-rise flats, Ponte Towers in Johannesburg, by squatters. ${ }^{47}$ By contrast, this book-perhaps because one of the researchers grew up in Kenneth Gardens - tells a much quieter story of 'community' and 'resilience'. The building fabric of Kenneth Gardens municipal housing estate has frayed at the edges during the post-apartheid era; but nonetheless it is relatively well-maintained because (bucking national trends) it was not privatised and still receives government subventions. At the same time, the increasing diversity of the residential community is obvious even to a curious passer-by. ${ }^{48}$ When the book's researchers surveyed Kenneth Gardens in 20II, they found that only I3 per cent of its inhabitants identified as 'white'. The livelihoods and life-ways of the residents living in Kenneth Gardens has diversified too, providing an idiosyncratic snapshot of a particular slice of post-industrial Durban. There are blue-collar working-class families; a handful of upwardly mobile government officials; old age pensioners and unemployed people dependent on a community-run soup kitchen; and a number of flashy cars parked outside the flats, suggestive of the livings earned from informal/illegal livelihoods. From being a bastion of the apartheid project, Kenneth Gardens, like many other former white working-class suburbs, has become 'one of the most socially diverse living spaces in the city'. ${ }^{49}$

The final book under review considers the post-apartheid transformation of the migrant hostels which housed labour migrants working in the city who were considered temporary sojourners under apartheid pass laws. Nomkhosi Xulu-Gama's book, Hostels in South Africa: Spaces of Perplexity (20I8), is important for being, I believe, the first monograph in nearly two decades to be published on the recent history of the South African dormitory hostels that were built in the

46 A. Morris, Bleakness and Light: Inner City Transition in Hillbrow (Johannesburg, 1999); M. Murray, City of Extremes: The Spatial Politics of Johannesburg (London, 20II).

47 N. Dechmann, F. Jaggi, K. Murbach, N. Ruffo and M. Mokgadi, Up Up: Stories of Johannesburg's Highrises (Johannesburg, 20I6); A. Simone, 'Resource of Intersection: Remaking Social Collaboration in Urban Africa', Canadian Journal of African Studies, xxxvii (2003), pp. 513-38; M. Subotzky, P. Waterhouse and I. Vladislavic, Ponte City (Göttingen, 20I4).

48 When I first lived in South Africa in 2002 I would walk past Kenneth Gardens most weeks.

49 D. Schensul and P. Heller, 'Legacies, Change and Transformation in the Post-Apartheid 

townships. ${ }^{50}$ The comparative lack of recent research on the migrant hostels is surprising. For the earlier generation of social historians, the hostels were the central institutions of apartheid and, more broadly, South Africa's urban history: housing an exploited migrant workforce, whose 'cheap labour' fuelled South Africa's mining and industrial economy. The relationship between migrant hostels and industrialisation and urbanisation is commonly traced back to South Africa's 'mineral revolution'. Closed compounds - that is, fenced-in, single sex, dormitory barracks run by the mining companies adjacent to the pitheads - were first established by De Beers at the Kimberley diamond mines in 1872 to stop diamond theft from its mines. From the company town of Kimberley, the migrant hostels spread to the gold mines of Johannesburg, the sugar plantations of Natal, and eventually across all the cities of South Africa during the first decades of the twentieth century. ${ }^{51}$

During apartheid, government policy took a new twist. Apartheid pass laws distinguished between black 'urban insiders' and 'migrant outsiders. The former (some 50 per cent of the black African population) were granted rights to live in segregated, purpose-built government township housing; the latter were classified as citizens of the 'Tribal/ Native Reserves', and were generally expected to sojourn in dormitory barracks/hostels when working in the cities. ${ }^{52}$ Radical historians described the tentacles of 'apartheid's labour empire' that spread across southern Africa. For in the late I980s, the labour migrant workforce that journeyed to the mines each year peaked, numbering around 730,000. ${ }^{53}$ Just as important were the dormitory hostels established next to the racially segregated townships and factory estates. Take the example of the metals industry, which was crucial to the apartheid government's industrial and manufacturing strategy. Its migrant labour force averaged 50 per cent across the sector as a whole, rising to 80 per cent in the foundries, whose hard and dangerous work of handling molten, liquid ore gave them a fearsome reputation. At the start of

50 G. Elder, Hostels, Sexuality, and the Apartheid Legacy: Malevolent Geographies (Athens, $\mathrm{OH}, 2003)$. Note, by contrast, the extensive literature on the transformation of the 'closed dormitory compounds' where mineworkers lived, which is summarised by A. Bezuidenhout and S. Buhlungu, 'From Compounded to Fragmented Labour: Mineworkers and the Demise of Compounds in South Africa', Antipode, xliii (2010), pp. I-27.

51 Beinart, South Africa, pp. 25-34, 59-67, I22-30, I49-58; P. Harries, Work, Culture and Identity: Migrant Labourers in Mozambique and South Africa, c.I860-I9Io (London, 1994); R.V. Turrell, Capital and Labour on the Kimberley Diamond Fields (Cambridge, 1987); W. Worger, South Africa's City of Diamonds: Mineworkers and Monopoly Capitalism in Kimberley, I867-95 (London, 1987).

52 D. Hindson, Pass Controls and the Urban African Proletariat (Johannesburg, 1987).

53 D. Coplan, In the Time of Cannibals: The Word Music of South Africa's Basotho Migrants (London, 1994); J. Crush, A. Jeeves and D. Yudelman, South Africa's Labour Empire: A History of Black Migrancy to the Goldmines (Cape Town, 199I); D. Moodie with V. Ndatshe, Going for Gold: Men, Mines and Migration (London, 1994). 


\section{Page i6 of I7 WRITING THE HISTORIES OF SOUTH AFRICA'S}

the I980s one study enumerated 400 government-run migrant hostels: 530,000 men sharing 300,000 dormitory beds. ${ }^{54}$

This urban landscape of labour migration was first described in devastating detail by sociologists and historians of 'cheap labour', such as Harold Wolpe; by photographers including David Goldblatt, Peter Magubane and Santu Mofokeng; and in the lyrics of jazz trumpeter Hugh Masekela's Stimela (The Train), which recounts the heartbreaking journeys made to 'the golden mineral mines'. Masekela's words derive their lyrical power from personal experience. He was born in the coal-mining and steel town of Witbank, at a railway junction that served the Pretoria-Witwatersrand-Vereeniging (PWV) urban conurbation with a steady diet of migrant workers and raw materials.

In the post-apartheid period, just as Kenneth Gardens residents have changed, so too the migrant hostels have been reconfigured by both the collapse of apartheid's pass laws and South Africa's industrial decline, which has particularly hit blue-collar migrant workers. The front cover of Xulu-Gama's book encapsulates her argument brilliantly: it is a photograph of a mother with a child on her back, washing up in a dilapidated hostel kitchen. (Both mother and child wear hats and are warmly dressed, for one presumes the windows are broken.) During apartheid, most migrant hostels were spaces inhabited by men who had come to the cities to earn wages that would be channelled back to families living in the rural areas. Ukupangela-a word that migrants' often used to describe 'working for the whites' in the mines or in the cities-literally means 'to rob or plunder'. A handful of social historians brilliantly described the patriarchal 'moral economy' of the migrant hostels during the apartheid era. Many dormitory rooms were governed by foremen, elders, headmen, who nepotistically found bluecollar work for their home-boys and made sure that juniors did not 'eat' I6.30 (that is, waste) their money in the cities. ${ }^{55}$ Xulu-Gama's contribution to this debate is to show how apartheid patterns of labour migration have collapsed during the post-industrial, post-apartheid era. Despite the best attempts of the post-apartheid government to turn the hostels into family and community residential units, the fabric of most migrant hostels has crumbled as they have turned into slum accommodation for some of the poorest residents in the city. These places are characterised as places of violence and nests of criminality-places where moral economies are so broken that unmarried women now prostitute themselves inside the dormitories. ${ }^{56}$ The great achievement of Xulu-Gama's book is to

54 M. Mamdani, Citizen and Subject: Contemporary Africa and the Legacy of Late Colonialism (London, 1996), pp. 218-84; A. Sitas, 'African Worker Responses On The East Rand To Changes In The Metal Industry, 1960-I980' (Univ. of Witwatersrand Ph.D. thesis,1983).

55 Moodie, Going for Gold, pp. II9-58.

56 The more thoughtful literature on migrant violence includes: D. Donham Violence in a Time of Liberation: Murder and Ethnicity at a South African Goldmine (Durham, NC, 20II); G. Kynoch, We are Fighting the World, pp. II5-56; G. Marinovitch, Murder at Small Koppie: The Real Story of the Marikana Massacre (Athens, $\mathrm{OH}, 2018)$. 
Writing THE Histories OF SOUTH AFriCA's Page I7 of I7 show sympathetically the complex life-ways of this new generation of peripatetic migrants, who hustle for a living on the fringes of the city. These are characterised by uncertainty, informality and vulnerability, she argues - hence the book's subtitle, 'places of perplexity'.

As these books suggest, the field of urban history has opened out in South Africa in recent years. If the social historians of the I980s associated with the Wits History Workshop mainly came out of a relatively tight set of Anglo-South African networks, the post-apartheid era has seen a wider set of interventions made by a broader range of urban studies scholars. Important too, is the diversity of research and publishing networks. Admittedly, one possible outcome of this diversity is fragmentation - and South Africans have written jeremiads warning that researchers and publishing houses of the Global North sometimes overlook the dynamism of South African debates. ${ }^{57}$ At the same time, South African research networks remain very strong institutionally, and there are a dozen or so research units in the main cities of the country, most with a pipeline of postgraduate students and postdoctoral fellowships. The University of Witwatersrand alone includes the Centre for Urbanism and Built Environment Studies (CUBES); a National Research Foundation Chair in Local Histories and Present Realities, led by stalwarts of the Wits History Workshop; the Wits Institute of Social and Economic Research (WISER); and the Sociology of Work Project (SWOP), a unit set up by trade union activists in the I970s. The University of Johannesburg's Centre for Social Research and the Centre for Civil Society at the University of KwaZulu Natal are two more important nexuses of radical research, which largely focus on urban studies and urban history. This dynamism of intellectual debate, which has its roots in the social history debates of the I970s and I980s, is one of the reasons why South Africa remains an important centre of urban historical studies a quarter of a century after the end of apartheid.

University College London

TIMOTHY GIBBS

57 For one public statement (albeit in a different field of study) of opinions that are widely expressed in private: N. Nattass, 'Review-Claire Decoteau: Ancestors and Anti-Retrovirals: The Biopolitics of HIV/AIDS in Post-Apartheid South Africa', African Studies Review, lvii (20I4), pp. 226-8. More broadly: J Currey, 'The State of African Studies Publishing', African Affairs, 